\title{
CYP39A1 Gene
}

National Cancer Institute

\section{Source}

National Cancer Institute. CYP39A1 Gene. NCI Thesaurus. Code C114642.

This gene is involved in bile acid metabolism. 